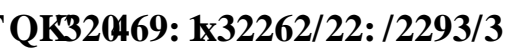

\title{
THE APPLICATION OF RISK ANALYSIS IN THE ASSESSMENT AND MANAGEMENT OF ROAD SAFETY IN ROAD TUNNELS
}

\section{ZASTOSOWANIE ANALIZY RYZYKA DO OCENY I ZARZĄDZANIA BEZPIECZEŃSTWEM RUCHU W TUNELACH DROGOWYCH}

\author{
Kazimierz Jamroz \\ Department of Highway Engineering, Faculty of Civil Engineering and Environment, \\ Gdansk University of Technology, 11 Narutowicza str., 90-952 Gdansk, Poland \\ Katedra Inżynierii Drogowej, Wydział Inżynierii Lądowej i Środowiska, \\ Politechnika Gdańska, ul. Narutowicza 11, 90-952 Gdańsk, Polska \\ e-mail: kjamroz@pg.gda.pl
}

\begin{abstract}
Road tunnels are highly sensitive to disturbance caused by road accidents. The most serious accidents occurring in tunnels involve trucks carrying hazardous materials. Europe has been developing methods of risk analysis and building models for traffic management in tunnels. Poland is only just beginning to build road tunnels and the area of tunnel safety has not been given adequate attention yet.
\end{abstract}

Key words: road safety, tunnels, risk management

Streszczenie. Tunele drogowe są najbardziej wrażliwymi na zakłócenia, spowodowane wypadkami, elementami sieci drogowej. Najpoważniejszymi wypadkami $w$ tych obiektach są zdarzenia $\mathrm{z}$ udziałem samochodów ciężarowych przewożących materiały niebezpieczne. Od kilku lat zatem rozwijane są w Europie metody analizy ryzyka i budowane narzędzia do zarządzania ryzykiem $w$ tunelach drogowych. W Polsce zaczyna się budować tunele drogowe, a problem bezpieczeństwa w tych obiektach jest jeszcze mało rozpoznany.

Slowa kluczowe: bezpieczeństwo ruchu drogowego, tunele, zarządzanie ryzykiem. 


\section{THE APPLICATION OF RISK ANALYSIS IN THE ASSESSMENT AND MANAGEMENT OF ROAD SAFETY IN ROAD TUNNELS}

\section{Introduction}

Norway is the country with the highest number of tunnels in Europe. There are 844 road tunnels of total length of $768 \mathrm{~km}$, including 309 tunnels of the length over $500 \mathrm{~m}$. Within the framework of fire safety in road tunnels in Norway since the beginning of the 1990's the compulsory risk analyses for the tunnels over $500 \mathrm{~m}$ have been conducted. The risk analysis is carried out for the existing and planned tunnels as well as for the tunnels through which the hazardous substances are transported. The assessment of safety concerns the construction of a tunnel, its equipment and the plan of emergency action [1].

Since the implementation of the Zero Vision Programme the risk analysis in Norway has been used more and more often as the basis for selection of priorities in road transport. In spite of the fact that accidents in tunnels do not contribute largely to the general number of accidents on the road network of Norway, the Norwegian Ministry of Transport and Communication decided in a new Plan of Transport Development for 2006 -2015 of the importance of improving tunnel safety because of the severity of consequences of a potential accident [2].

In the European Union there are 512 tunnels (mainly in Italy, Austria, Germany, France and Greece). Heavy goods vehicles, especially vehicles transporting dangerous goods present the main danger in tunnels. The basic cause of the accidents is the dangerous behaviour of drivers i.e. exceeding speed limit and drunk driving. The fire of a passenger car in a tunnel lasts about $10-30$ minutes and release the energy of about $3-10 \mathrm{MW}$, whereas the fire of a heavy duty vehicle lasts from $1-4$ hours and releases the energy of $30-150 \mathrm{MW}$. The temperature up to 700 degrees Celsius reaches even 500 meters into the tunnel depending on the direction of airflow [3].

During several past years few extremely dangerous accidents occurred, which took place among others: in the Mont Blanc tunnel in France in 1999, where 39 people died as a result of few days long fire, in the St. Gotthard tunnel caused by a drunk driver where 11 people died (fig.1) and in the Tauren tunnel where 12 people died. The estimates are that the annual losses 
in fires and due to the reconstruction of the tunnels at that time amounted to 210 million Euros per year. Whereas the losses related the tunnels' closure amounted to 450 million Euros per year. [4].

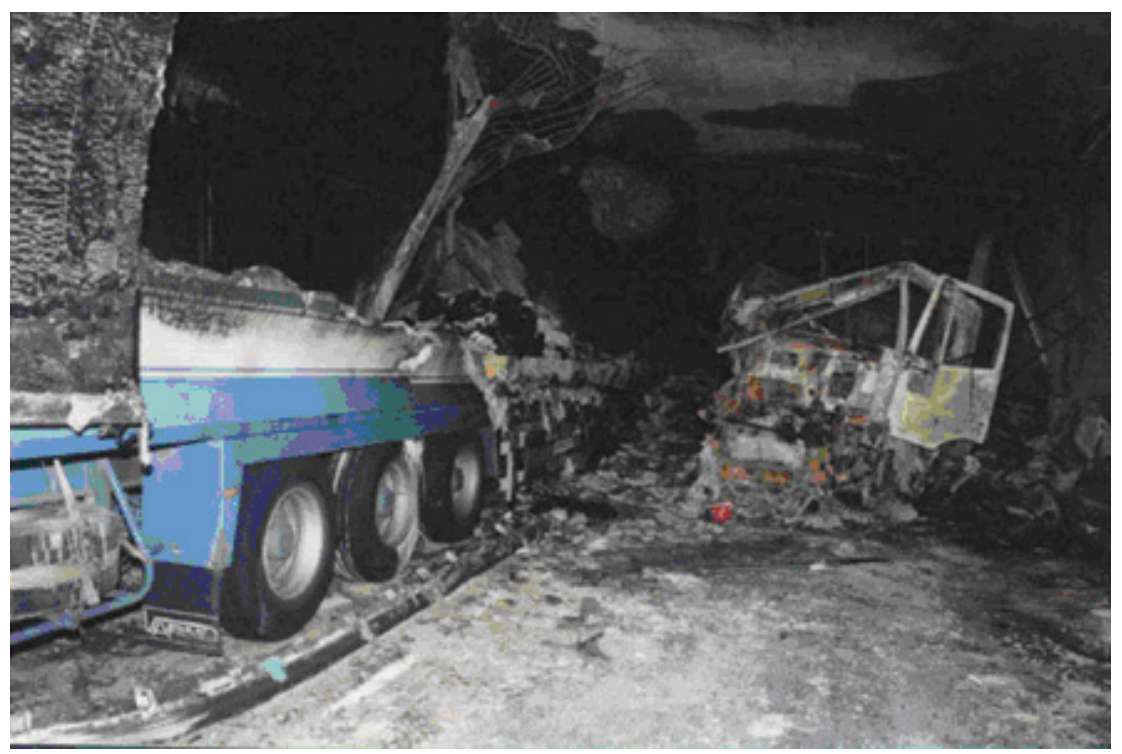

Fig. 1. The scene of accident in St. Gotthard road tunnel which was caused by a drunk driver [5]

As the result of the accidents the European Union, apart from the existing national regulations, developed and issued a special Directive 2004/54/EC EU on minimal safety requirements in road tunnels belonging to the TransEuropean Road Network TERN [6]. The Directive defines the guidelines concerning: the construction of a tunnel and safety equipment, safety management, requirements for participants and accidents management.

\section{Risk management in tunnels}

The road tunnels are the element of road network where the occurring accidents involve large number of victims and high cost. Therefore, for many years various guidelines, rules, recommendations and handbooks have been developed and improved for the assessment and management of road safety in that kind of objects. The introduction of the methods of analysis and assessment of the risk in safety management of chemical works and atomic plants brought about the adaptation of this method in the safety management in road tunnels. 
The works have been carried out both on the grounds of particular, interested countries and international organizations. The example is the project designed by the OECD. The studies, which covered 33 long road tunnels, lead to development of quality method of risk assessment in QRAM tunnels and was used to select the most efficient actions to decrease the risk of accident in a tunnel [7].

\subsection{The risk analysis}

In the road tunnels risk analyses the risk standards are selected depending on the method: personal risk, social risk, economical as well as risk of damage on tunnel construction and on environment.

In 1991 in Switzerland the regulation on protection against major risks (OPAM), which introduced the obligation to carry out risk analyses also on the roads where hazardous goods are transported. The method applied consists in the setting the probability of the major transportation catastrophe occurrence (the death of at least 10 people, significant surface water or groundwater contamination).

In the risk-based analyses several groups of representative scenarios are analysed:

1. The risk related to people: (scenario „fire”, „explosion”, and "toxic gases release"),

2. The risk for surface water

3. The risk for groundwater

The probability of the occurrence of the emergency scenarios is calculated in relation to many factors i.e. the traffic volume, the share of heavy duty vehicles in the traffic, the share of vehicles transporting hazardous substances, the indicator/ ratio of accident occurrence on selected road type, probability of the release of hazardous substance, population in the vicinity of a road and the type of tunnel [8].

In the QRAM method developed by OECD the four groups of risk indicators were assumed: social risk (group), personal risk, risk of damage on tunnel construction and on environment. The 13 representative scenarios of dangerous incident in a tunnel were developed and divided into three basic categories: fire, explosion (fire plus fumes e.g. benzine) and release of toxic gases (chlorine, ammonia). Figure 2 presents the example of supplementary distributant $\mathrm{F} / \mathrm{N}$ for selected hazardous substances transportation on roads [9].

The calculation of scenario occurrence probability is realized in the following steps: 


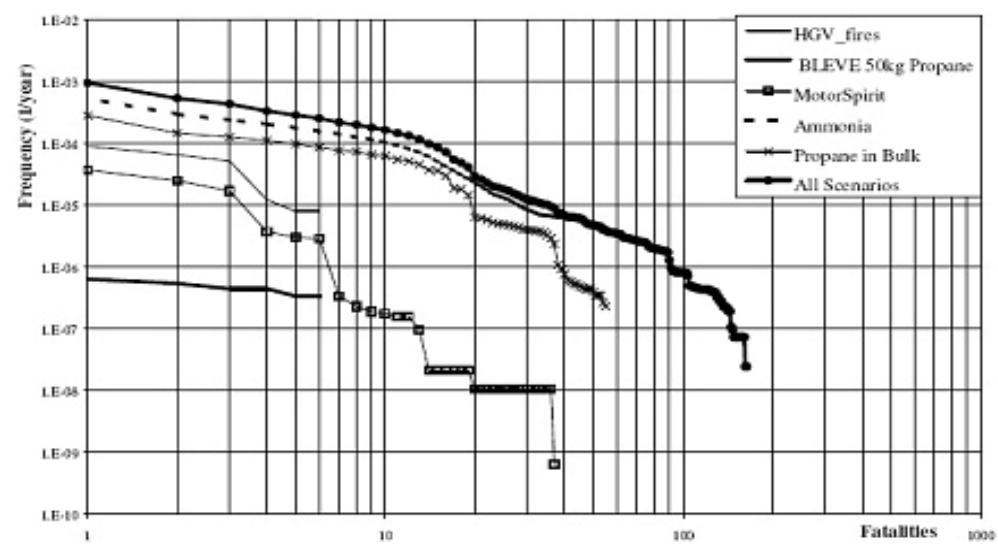

Fig. 2. The example of supplementary distributant $\mathrm{F} / \mathrm{N}$ for selected hazardous substances transportation [9].

1. First the indicator of accidents with heavy duty vehicles (carrying or not dangerous goods) is defined for particular countries, built-in area, rural area, separated or not separated carriageways, the type of road surface.

2. Then the share of heavy duty vehicle and vehicle transporting dangerous goods in a year on analysed road is defined.

3 . Then the share of accidents with heavy duty vehicles where the fire reaches the energy up to $20 \mathrm{MW}$ and $100 \mathrm{MW}$ is defined.

4. Finally the probability of scenario with the specific type of accident is defined.

Steps 1, 3 and 4 are carried out with the use of a model, whereas step 2 is defined by a person performing calculation.

The important factor which has an impact on the consequences of dangerous accident in road tunnel is the number of tunnel "pipes" and the distance from the fire or explosion epicenter. Figure 3 presents the dependence of the injured and fatalities share in accident from the distance to the epicenter of the accident.

\subsection{Risk assessment}

In Swiss method accepted risk level related to the occurrence of grave transport catastrophe with hazardous substances, in case of threat for people is: the probability $\leq 1,010^{-5}$ (per $1 \mathrm{~km}$ per year) of life loss of at least 10 people [8]. Figure 4, though, presents the criteria of social risk acceptance commonly used in road tunnels. 


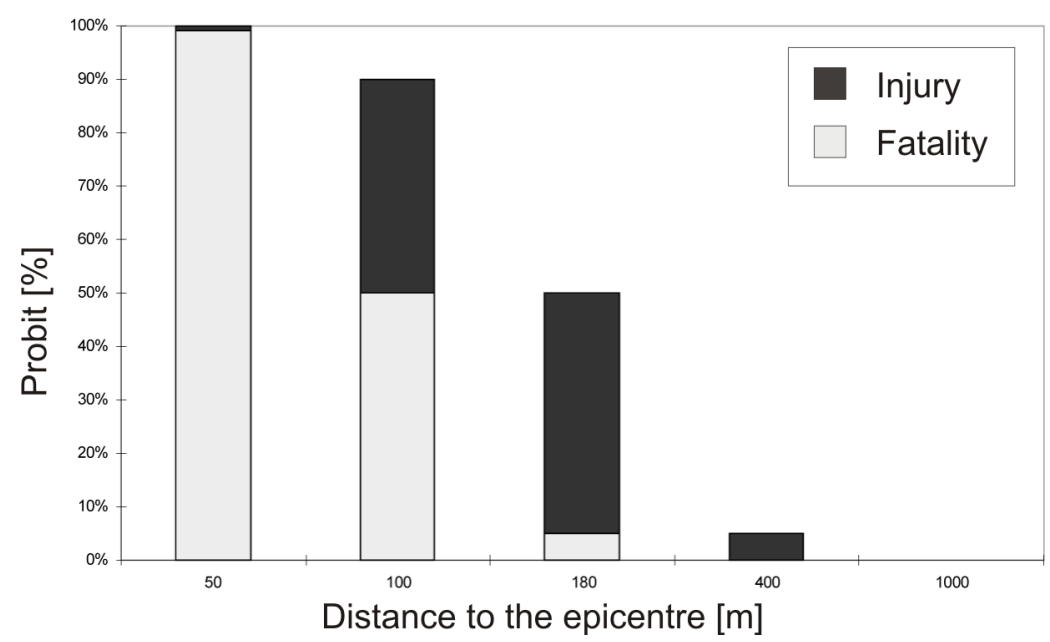

Fig. 3 The share of fatalities and injured in a road tunnel depending on the distance from the epicenter of dangerous accident [7]

\subsection{Risk assessment}

In Swiss method accepted risk level related to the occurrence of grave transport catastrophe with hazardous substances, in case of threat for people is: the probability $\leq 1,010^{-5}$ (per $1 \mathrm{~km}$ per year) of life loss of at least 10 people [8]. Figure 4, though, presents the criteria of social risk acceptance commonly used in road tunnels.

The curve (1) presents the highest limit of acceptance used in Great Britain [11], curve (2) presents the highest limit proposed by Trobjevica [12], curves (3 and 4) are accepted as a high and low risk limit in Holland [13], curve 5 as a high risk limit in Austria [14] and suggested as a low limit by Trojevica. The above comparison proves that particular countries establish individual, very different limits of risk acceptance in road tunnels. 


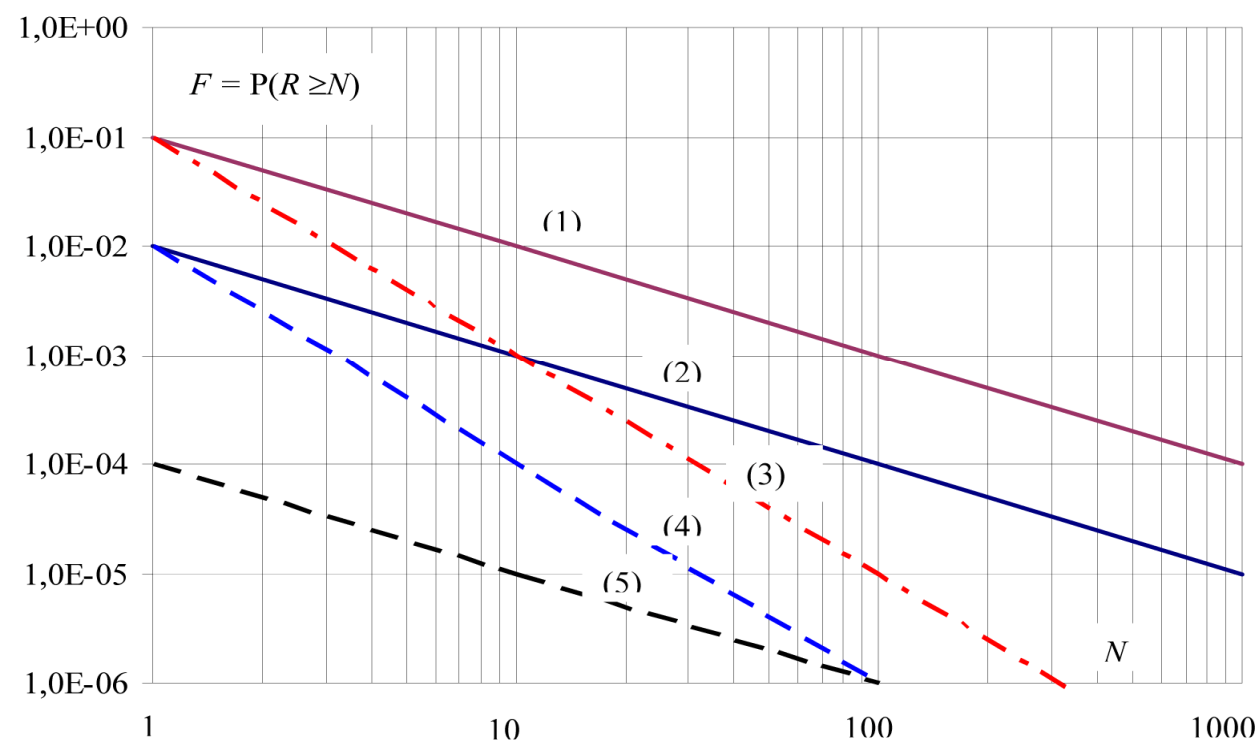

Fig. 4. The criteria of social risk acceptance commonly used in road tunnels [10].

\subsection{Risk reduction and control}

One of the analyses conducted as a part of safety assessment of a tunnel under construction is the risk assessment in a planned tunnel and on the possible alternative roads. The assessment procedure adopted in France has few stages. In the first one, the IR indicator is calculated and it is assessed whether passing through the analysed tunnel with dangerous materials fulfills the accepted safety criteria. If not, the alternative roads for dangerous materials transportation are analysed and the consequences of passing through them are compared with the consequences of passing through the tunnel. If there is no alternative roads or the consequences of passing through them is more dangerous than through the tunnel then the additional protection measures are applied which allow for reduction of risk during the transport of dangerous materials [15].

Within the framework of the studies with the use of QRAM method, OECD carried out the assessment of effectiveness of 27 different activities which influence the reduction of risk in road tunnels [7]. On this ground they developed the tools supporting decision making and the selection of effective activities. Among analysed and recommended activities for the reduction of risk in road tunnels the following were distinguished: 
- Activities to reduce the accident risk:

- Related to tunnel design and exploitation: cross-section, (separated carriageways), visibility, geometrical parameters, lighting and road surface (tightness)

- Related to vehicles and road traffic: speed limit, no overtaking, convoy assembly, distance between vehicles, vehicles control,

- Activities to reduce the accident consequences:

○ transferring information to operator and emergency system: internal television, automatic accident detection, fire detection, local radio (service), automatic vehicles identification, emergency telephones,

o information for tunnel users: emergency telephones, local radio (tunnel users), alarms and signals, speakers,

○ users evacuation and protection: safety exits, smoke control, lighting (emergency), rescue equipment, error management,

- reducing the severity of accidents: fire equipment, rescue team, draining off water, road surface, emergency plan, escort,

- reducing the consequences in tunnel: fire brigade structure, antiexplosion service structure.

The following tools will help decision makers to:

- assess the risk in existing and planned road tunnels,

- select the variant of road with or without tunnel,

- select effective activities to reduce the risk in case of construction of a tunnel,

- inform local society about possible threats resulting from tunnel exploitation.

\section{Conclusion}

Recently in Poland the tunnels over 500 metres long have been built in Warsaw and Katowice and the further are planned, among others 3 tunnels in Tricity. One of them which will run under the Martwa Wisła (Dead Vistula) in the scheme of Sucharski Route (linking Gdańsk Port with the national roads network) will be about $0.8 \mathrm{~km}$ long and will take over the transit traffic (including vehicles with dangerous good to the port and factories situated in the port district of the city) from densely populated centre of Gdańsk.

The analysis of Sucharski Route efficiency (including tunnel) shows that its construction will cause in the year of the opening for traffic (2012) [16]:

- Shortening the total journey time by $7.9 \mathrm{mln}$ hours/year, 
- Decrease in the use of fuel by $10.8 \mathrm{mln} 1 / y e a r$,

- Decrease in the emission of $\mathrm{CO}_{2}$ by $0.7 \mathrm{mln}$ tonnes/year, a NOx by 0,1 mln tonnes/year,

- Decrease in the number of road incidents by 313 accidents and collisions/year and accidents victims by 44 persons/year,

- Decrease in the total costs of traffic by $166 \mathrm{mln}$ PLN/year.

Whereas the risk of occurrence of catastrophe with more than 10 fatalities per $1 \mathrm{~km}$ per year (according to Swiss method) may amount to:

- In the tunnel under the Martwa Wisła:

- In case of two separated carriageways: $\mathrm{P}=1.3610^{-6}$,

○ In case of one carriageway: $\quad \mathrm{P}=2.6210^{-6}$,

- On the alternative router through the city centre: $\mathrm{P}=5,3810^{-6}$.

The above calculations show that the risk of the occurrence of catastrophe with more than 10 fatalities in a planned tunnel is low and does not exceed the risk accepted according to criteria presented in fig. 4.

The calculation are, however, simplified and do not consider Polish conditions. Therefore it is necessary to elaborate Polish method of risk management in road tunnels including conditions of Polish traffic and the behaviour of traffic participants.

\section{Bibliograhy:}

[1]. OECD: Studies in Risk Management Norway TUNNEL SAFETY. OECD (2006) OECD Publications, 2, rue André-Pascal, 75775 Paris Cedex 16, France

[2]. NMTC: Nasjonal transportplan 2006-2015. Norwegian Ministry of Transport and Communication, Oslo, 2004

[3]. UN: Recommendations of the group of experts on safety in road tunnels. Final report. Economic Commission for Europe, Inland Transport Committee, TRANS/AC.7/9, December 2001

[4]. EC DGET: Safety in European Road Tunnels. European Commission Directorate General for Energy and Transport, 2002.

[5]. Thamm B. The new Directive 2004/54/EC on Road Tunnel Safety and its consequences. EU 2004.

[6]. EU DGT: Dyrektywa 2004/54/WE Parlamentu Europejskiego i Rady z dnia 29 kwietnia 2004 r. w sprawie minimalnych wymagań bezpieczeństwa dla tuneli w transeuropejskiej sieci drogowej. Dziennik Urzędowy Unii Europejskiej L 167/39, 2004 
[7]. OECD: Safety in tunnels. Ttransport of dangerous goods through road tunnels. OECD (2001) OECD Publications, 2, rue André-Pascal, 75775 Paris Cedex 16, France

[8]. Borysiewicz M., Potempski S.: Praktyczne algorytmy ocen ryzyka dla człowieka i środowiska od szlaków transportu niebezpiecznych substancji. Instytut Energii Atomowej, Otwock - Świerk 2001.

[9]. Lacroix D. at al. Transport Of Dangerous Goods Through Road Tunnels: An Integrated QRA Model Developed. Under The Joint OECD/PIARC Project ERS2. 1999

[10]. Holický M.:Risk criteria for road tunnels. Special Workshop on Risk Acceptance and Risk Communication. Stanford University, 2007.

[11]. Vrouwenvelder A.C.W.M. \& Krom A.H.M. (2004) Hazard and the Consequences for Tunnels Structures and Human Life. 1st International Symposium Safe and Reliable Tunnels in Prague, CUR, Gouda, The Netherlands, 2004.

[12].Trobjevic V. M. (2003) Development of Risk Criteria for Road Tunnels. 5th International Conference - Safety in Road and Rail Tunnels. Marseille, 2003.

[13]. Worm, E.W. and Hoeksma, J. (1998) The Westerschelde Tunnel: Development and application of an integrated safety philosophy, Safety in Road and Rail Tunnels, 3rd International Conference organised by University of Dundee and ITC Ltd., Nice, France, 1998.

[14]. Knoflacher H. and P.C. Pfaffenbichler (2004) A comparative risk analysis for selected Austrian tunnels. 2nd International Conference Tunnel Safety and Ventilation, Graz, 2004.

[15]. DGR: Guide to Road Tunnel Safety Documentation. Booklet 3, Risk analyses relating to dangerous goods transport. Directoriate Generale des Routes, Centre d'Etudes des Tunnels, Paris, France 2005

[16]. Jamroz K., Oskarbska I. i inni: Analizy i prognozy ruchu dla Trasy Sucharskiego w Gdańsku oraz wyniki obliczeń dla potrzeb analizy społeczno - ekonomicznej. TRAFIK, Gdańsk 2007. 


\section{ZASTOSOWANIE ANALIZY RYZYKA DO OCENY I ZARZĄDZANIA BEZPIECZEŃSTWEM RUCHU W TUNELACH DROGOWYCH}

\section{Wstęp}

Norwegia jest krajem o największej liczbie tuneli w Europie. Obecnie są tam 844 tunele drogowe o łącznej długości $768 \mathrm{~km}$, w tym 390 tuneli o długości większej niż $500 \mathrm{~m}$. W ramach oceny bezpieczeństwa pożarowego $\mathrm{w}$ tunelach drogowych w Norwegii, od początku lat 90-tych ubiegłego stulecia, prowadzone są obowiązkowo analizy ryzyka dla tuneli o długości większej niż $500 \mathrm{~m}$. Analiza ryzyka prowadzona jest dla tuneli: istniejących i planowanych oraz tuneli przez które przewożone będą materiały niebezpieczne. Ocena bezpieczeństwa dotyczy zarówno konstrukcji tunelu, jego wyposażenia jak również planu akcji ratowniczej [1].

Od kiedy przyjęto Wizję Zero w Norwegii, analiza ryzyka wykorzystywana jest coraz częściej jako podstawa do wyboru priorytetów w sektorze transportu drogowego. Mimo, że wypadki drogowe w tunelach nie stanowia zbyt dużej części wypadków drogowych na sieci dróg w Norwegii, to jednak Ministerstwo Transportu Norwegii w nowym Planie Rozwoju Transportu na lata 2006 - 2015 za istotne uznało usprawnienie bezpieczeństwa $w$ tunelach ze względu na duże konsekwencje potencjalnych wypadków [2].

W Unii Europejskiej jest 512 tuneli (przede wszystkim we Włoszech, Austrii, Niemczech, Francji i Grecji). Główne zagrożenie w tunelach stanowią pojazdy ciężkie, a w szczególnie pojazdy przewożące materiały niebezpieczne. Podstawową przyczyna tych wypadków są niebezpieczne zachowania kierowców tj. nadmierna prędkość i jazda pod wpływem alkoholu. Pożar samochodu osobowego w tunelu trwa ok.10 - $30 \mathrm{~min}$ i wyzwala energię ok. 3 - $10 \mathrm{MW}$, natomiast pożar samochodu ciężarowego trwa od $1-4$ godz. i wyzwala energię $30-150$ MW. Temperatura o poziomie dochodzącym do 700 stopni Celsjusza sięga nawet do 500 metrów w głąb tunelu w zależności od kierunku przepływu powietrza [3]. W ostatnich kilkunastu latach doszło do kilku znaczących wypadków o dużej skali zagrożenia, które miały miejsce między innymi: w tunelu Mont Blanc we Francji w 1999 roku, gdzie w wyniku wielodniowego 
pożaru zginęły 39 osób), w tunelu Św. Gottharda spowodowanym przez kierowcę pod wpływem alkoholu, gdzie 11 osób zginęło (rys.1) i w tunelu Tauren, gdzie zginęło 12 osób (8 w wyniku wypadku i 4 w wyniku zaczadzenia). Szacuje się, że roczne straty pożarów i naprawy tunelów w tym czasie wynosiły $210 \mathrm{mln}$ EURO/rok. Natomiast straty związane z zamknięciem tuneli $450 \mathrm{mln}$ EURO/rok. [4] .

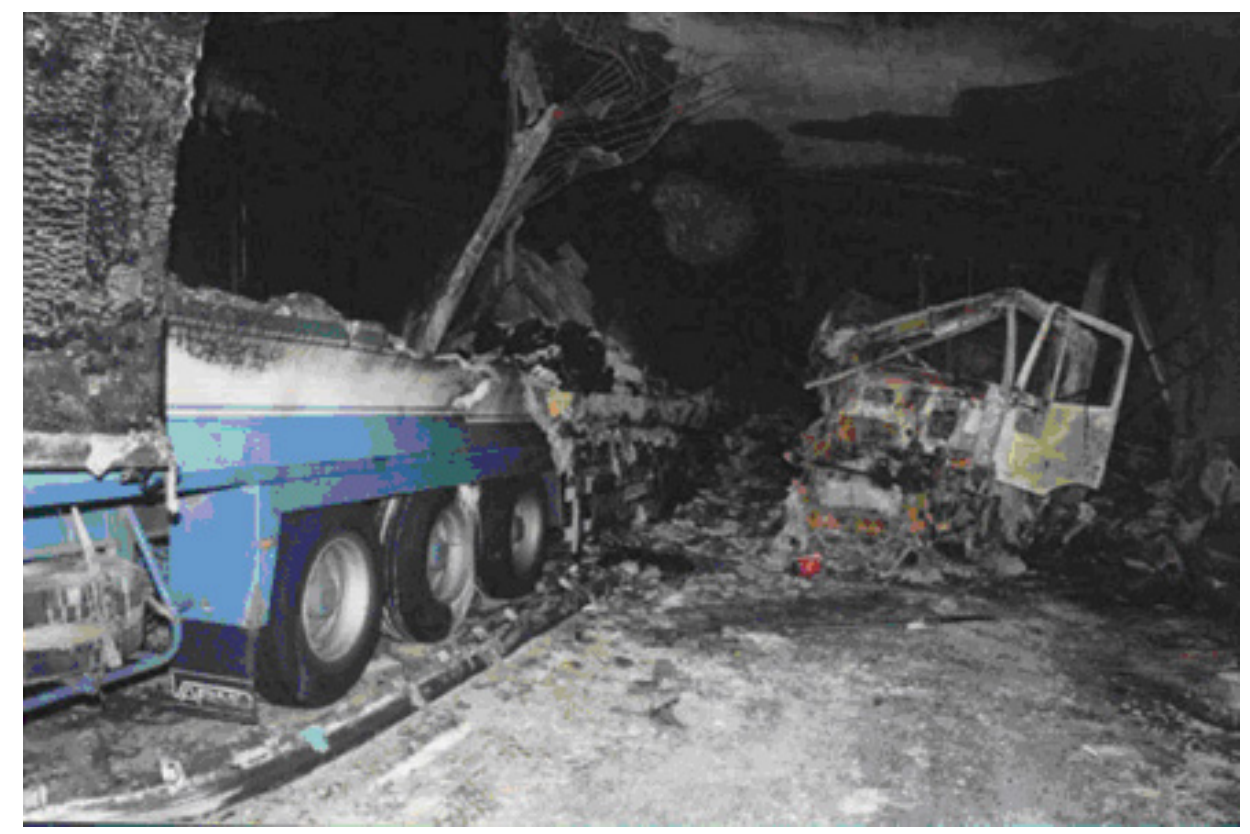

Rys. 1. Obraz po wypadku w tunelu drogowym Św. Gottharda, którego sprawcą był kierowca jadący pod wpływem alkoholu [5]

Te wypadki spowodowały, że poza uregulowaniami krajowymi opracowano i wydano w Unii Europejskiej specjalną Dyrektywę 2004/54/EC EU, dotycząca minimalnych wymagań bezpieczeństwa w tunelach drogowych Transeuropejskiej Sieci Drogowej TERN. [6]. W Dyrektywie tej określono zalecenia dotyczące: konstrukcji tuneli i urządzeń bezpieczeństwa, zarządzania bezpieczeństwem, wymagań do uczestników i zarządzania wypadkami.

\section{Zarządzanie ryzykiem $w$ tunelach}

Tunele drogowe są elementem drogi, gdzie mogą wystapić zdarzenia o dużej liczbie ofiar i dużych kosztach. Dlatego od wielu lat trwa rozwój 
i doskonalenie różnego rodzaju wytycznych, zasad, zaleceń i przewodników dla potrzeb oceny i zarządzania bezpieczeństwem ruchu drogowego $\mathrm{w}$ tego typu obiektach. Pojawienie się metod analizy i oceny ryzyka w zarządzaniu bezpieczeństwem zakładów chemicznych i elektrowni atomowych spowodowało jej adaptacje także do zarządzania bezpieczeństwem ruchu w tunelach drogowych. Prace prowadzono zarówno na poziomie poszczególnych zainteresowanych krajów jak i organizacji międzynarodowych. Przykładem są badania przeprowadzone przez OECD. Badaniami objęto 33 długie tunele drogowe, w wyniku których, opracowano metodę jakościowej oceny ryzyka w tunelach QRAM, którą zastosowano także do wyboru najbardziej efektywnych działań zmniejszających ryzyko wypadku w tunelu [7].

\subsection{Analiza ryzyka}

$\mathrm{W}$ analizach ryzyka $\mathrm{w}$ tunelach drogowych jako miary ryzyka przyjmuje się w zależności od metody: miary indywidualne, ryzyko społeczne i ryzyko ekonomiczne, a także uszkodzenia konstrukcji tunelu i degradację środowiska.

W 1991 roku w Szwajcarii wprowadzono rozporządzenie w sprawie ochrony przed poważnymi awariami (OPAM), w którym wprowadzono obowiązek wykonywania analizy ryzyka także na trasach po których transportowane są niebezpieczne materiały. Zastosowana metoda sprowadza się do wyznaczania prawdopodobieństwa wystapienia poważnej katastrofy transportowej (utratę życia w wypadku przez co najmniej 10 osób, znaczne zanieczyszczenie wód powierzchniowych lub wód podziemnych).

$\mathrm{W}$ analizach ryzyka analizuje się kilka grup scenariuszy reprezentatywnych dotyczących:

1. Zagrożeń w odniesieniu do ludności: (scenariusz „pożar”, „wybuch” i ,uwolnienie gazów toksycznych”),

2. Zagrożeń dla wód podziemnych,

3. Zagrożeń dla wód powierzchniowych.

Prawdopodobieństwo wystąpienia poszczególnych scenariuszy awaryjnych oblicza się w zależności od wielu czynników, wśród których wyróżnić można: wielkość natężenia ruchu pojazdów, udział pojazdów ciężkich $\mathrm{w}$ ruchu, udział pojazdów $\mathrm{z}$ materiałami niebezpiecznymi, wskaźniki wypadków na wybranych typach dróg, prawdopodobieństwo uwolnienia substancji powodującej zagrożenie, gęstość zaludnienia w otoczeniu drogi, rodzaj tunelu itp. [8]. 
W metodzie QRAM opracowanej przez OECD przyjęto cztery grupy wskaźników ryzyka: ryzyko społeczne (grupowe), ryzyko indywidualne, uszkodzenia konstrukcji tunelu i zagrożenia środowiska. Opracowano 13 reprezentatywnych scenariuszy niebezpiecznego zdarzenia $w$ tunelu reprezentujących trzy zasadnicze grupy: pożar, wybuch (pożar plus opary np. benzyny) oraz uwolnienie gazów toksycznych (chlor, amoniak). Na rys. 2 przedstawiono przykład dystrybuanty dopełniającej $\mathrm{F} / \mathrm{N}$ dla wybranych scenariuszy przewozu materiałów niebezpiecznych na drogach [9-1440].

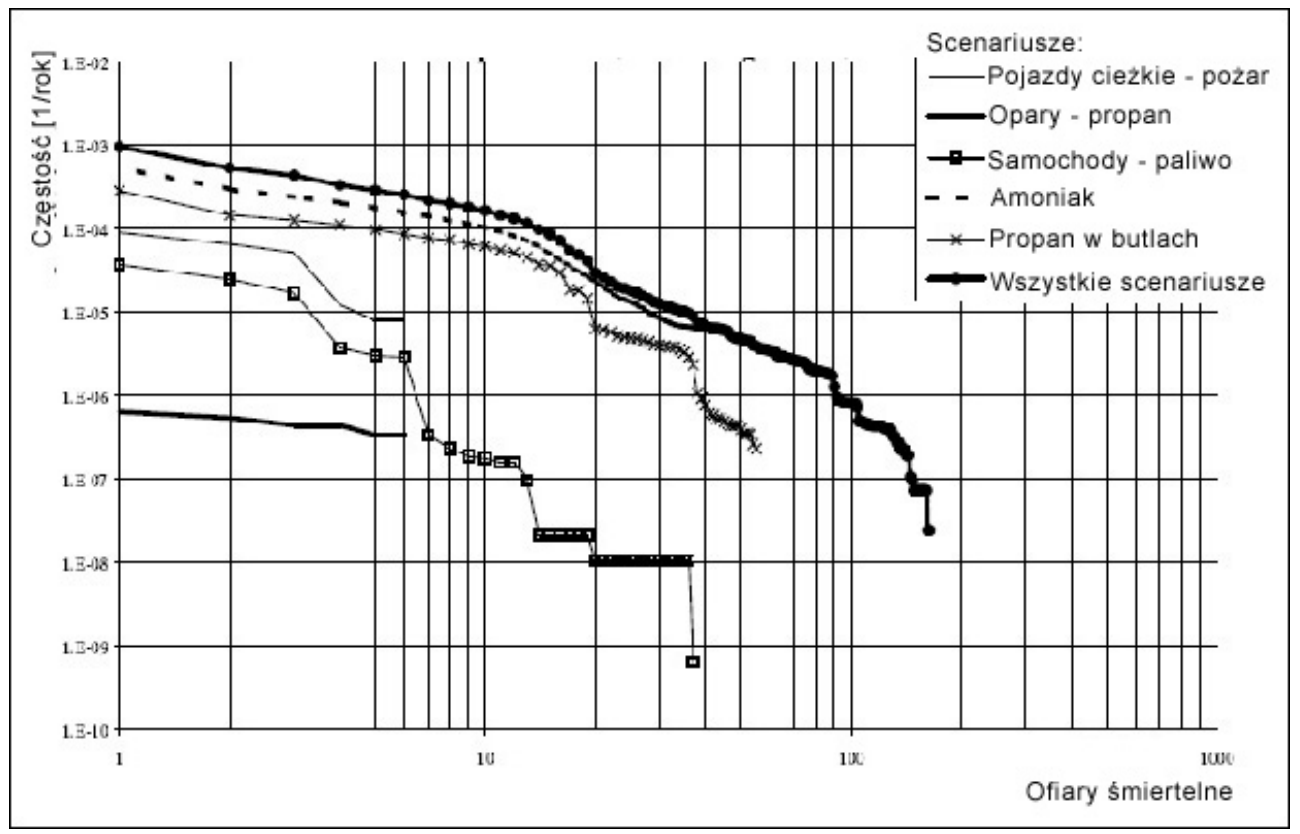

Rys. 2. Przykład dystrybuanty dopełniającej F/N dla wybranych scenariuszy przewozu materiałów niebezpiecznych [9].

Obliczenia prawdopodobieństwa wystąpienia danego scenariusza realizuje się za pomocą kilku kroków:

1. Najpierw określa się wskaźnik wypadków z udziałem pojazdów ciężkich (z i bez materiałów niebezpiecznych) dla poszczególnych krajów, obszaru miejskiego i zamiejskiego, rozdzielonych i nierozdzielnych jezdni dróg, rodzaju nawierzchni.

2. Następnie określa się udział ruchu pojazdów ciężkich i pojazdów $\mathrm{z}$ materiałami niebezpiecznymi w ciagu roku na analizowanej drodze. 
3. Potem określa się udział wypadków z pojazdami ciężkimi gdzie pożar osiaga energię do $20 \mathrm{MW}$ i $100 \mathrm{MW}$.

4. $\mathrm{Na}$ koniec określa się prawdopodobieństwo wystapienia scenariusza $\mathrm{z}$ danym rodzajem wypadku.

Kroki 1,3 i 4 realizowane są za pomocą modelu, natomiast krok 2 określany jest przez prowadzącego obliczenia.

Istotnym czynnikiem wpływającym na konsekwencje niebezpiecznego wypadku w tunelu drogowym jest liczba rur tunelu oraz odległość od epicentrum pożaru lub wybuchu. Na rys. 3 przedstawiono zależność udziału osób rannych i zabitych $\mathrm{w}$ wypadkach $\mathrm{w}$ zależności od odległości do epicentrum takiego rodzaju wypadku.

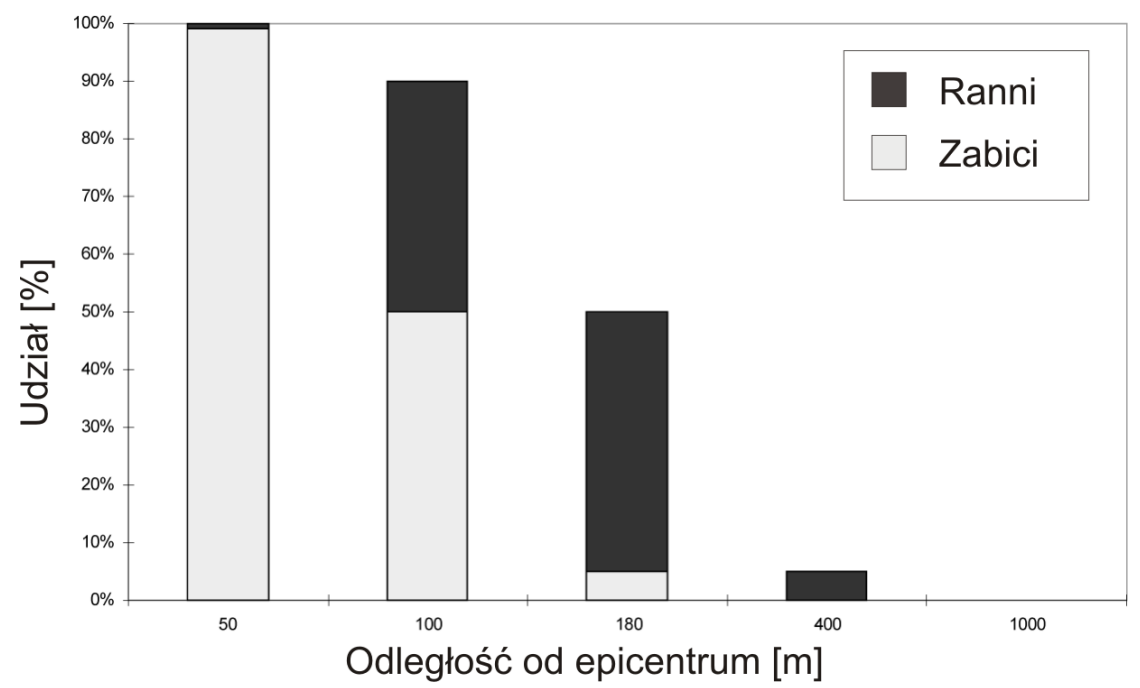

Rys. 3 Udział ofiar śmiertelnych i rannych w tunelu drogowym w zależności od epicentrum wypadku niebezpiecznego [7]

\subsection{Ocena ryzyka}

W metodzie szwajcarskiej jako akceptowalny poziom ryzyka związany $\mathrm{z}$ wystapieniem poważnej katastrofy transportowej $\mathrm{z}$ udziałem niebezpiecznych substancji, $\mathrm{w}$ przypadku zagrożenia ludzi przyjęto: prawdopodobieństwo $\leq 1,010^{-5}$ (w przeliczeniu na $1 \mathrm{~km}$ na rok) utraty życia przez co najmniej 10 osób [8].

Natomiast na rys. 4 przedstawiono kryteria akceptowalności ryzyka społecznego stosowane najczęściej w tunelach drogowych. Krzywa (1) odpowiada górnej granicy akceptowalności stosowana w Wielkiej Brytanii 
[11], krzywa (2) odpowiada górnej granicy zaproponowanej przez Trobjevica [12], krzywe (3 i 4) są przyjmowane jako górna i dolna granica ryzyka w Holandii [13], krzywa (5) przyjmowana jest jako górna granica w Austrii [14] i proponowana jako dolna granica przez Trobjevica. Przedstawionego porównania wynika, że poszczególne kraje ustalają własne, znacznie różniące się kryteria akceptowalności ryzyka $\mathrm{w}$ tunelach drogowych.

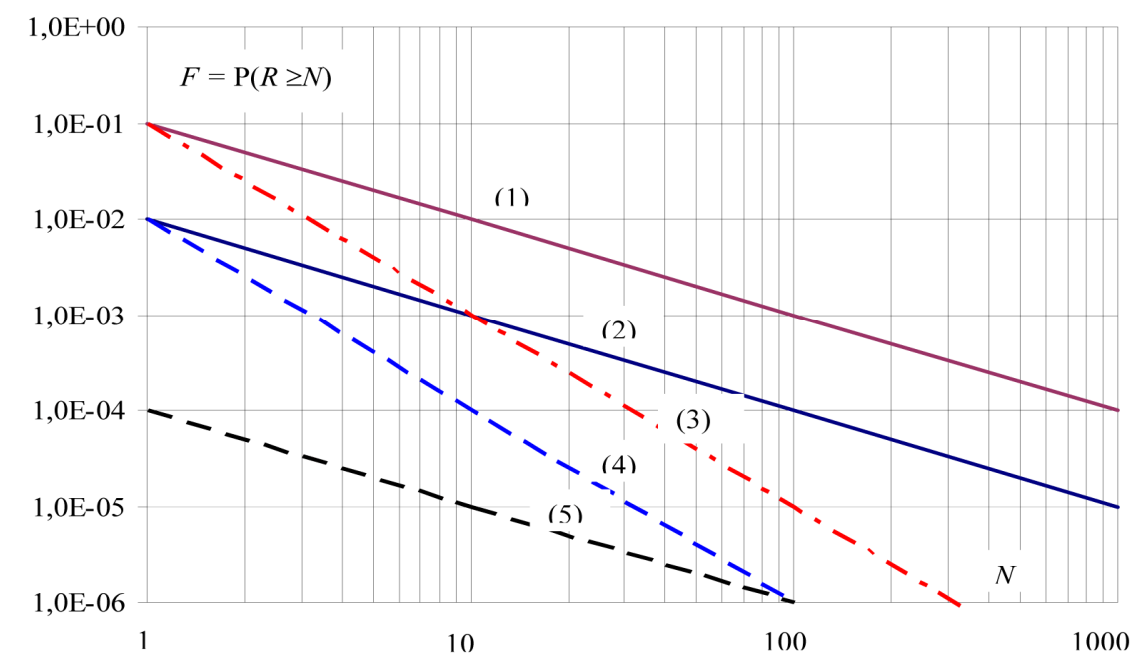

Rys. 4 Kryteria akceptowalności ryzyka w tunelach drogowych [10].

\subsection{Redukowanie i sterowanie ryzykiem}

Jedną $\mathrm{z}$ analiz prowadzonych $\mathrm{w}$ ramach oceny bezpieczeństwa projektowanego tunelu jest ocena ryzyka $\mathrm{w}$ planowanym tunelu $\mathrm{i}$ na ewentualnych drogach alternatywnych. Zastosowana we Francji procedura oceny ma kilka etapów. W pierwszym etapie oblicza się wskaźnik ryzyka IR i ocenia czy przejazd z materiałami niebezpiecznymi przez analizowany tunel odpowiada przyjętym kryteriom bezpieczeństwa. Jeżeli nie to analizuje się czy istnieją alternatywne drogi przewozu tych materiałów i porównuje się konsekwencje przejazdu po tych drogach z konsekwencjami przejazdu przez tunel. Jeżeli nie ma możliwości przejazdu drogami alternatywnymi lub przejazd po nich będzie bardziej niebezpieczny niż droga przez tunel to stosuje się dodatkowe zabezpieczenia pozwalające na zmniejszenie ryzyka przy przejeździe pojazdu $\mathrm{z}$ materiałami niebezpiecznymi [15].

$\mathrm{W}$ ramach badań prowadzonych przez OECD, z zastosowaniem metody QRAM przeprowadzono ocenę efektywności 27 różnych działań 
wpływających na zmniejszenie ryzyka w tunelach drogowych [7]. Na tej podstawie opracowano narzędzia wspomagające podejmowanie decyzji i wybór efektywnych działań. Wśród analizowanych i rekomendowanych działań na rzecz zmniejszenia ryzyka w tunelach drogowych wyróżniono:

- działania zmniejszające prawdopodobieństwo wypadku:

o odnoszace się do projektowania i eksploatacji tunelu: przekrój poprzeczny (rozdzielenie jezdni), widoczność, parametry geometryczne, oświetlenie, nawierzchnia drogi (szczelność),

o odnoszące się do pojazdów i do ruchu drogowego: limit prędkości, zakaz wyprzedzania, jazda w konwojach, odległość między pojazdami, kontrola pojazdów,

- działania zmniejszające konsekwencje wypadku:

o przekazywanie informacji do operatora i system ratownictwa: telewizja wewnętrzna, automatyczne wykrywanie wypadków, automatyczne wykrywanie pożarów, radio lokalne (obsługa), automatyczna identyfikacja pojazdów, telefony ratownicze,

o informacja dla użytkowników tunelu: telefony ratownicze, radio lokalne (użytkownicy tunelu), alarmy i sygnały, spikerzy,

- ewakuacja i ochrona użytkowników: wyjścia bezpieczeństwa, kontrola dymowa, oświetlenie (ratownicze), sprzęt ratowniczy, zarządzanie błędami,

○ zmniejszenie ważności wypadków: sprzęt przeciw pożarowy, zespól ratowniczy, odprowadzenie wody, nawierzchnia drogowa, plan ratowniczy, eskortowanie,

○ zmniejszenie konsekwencji w tunelu: struktura straży pożarnej, struktura służby przeciwwybuchowej.

Takie narzędzia pomagają decydentom $\mathrm{w}$ :

- ocenie ryzyka w istniejących i planowanych tunelach drogowych,

- wyborze wariantu trasy drogowej z lub bez tunelu,

- wyborze efektywnych działań zmniejszających ryzyko w przypadku budowy tunelu,

- informowaniu lokalnego społeczeństwa o możliwych zagrożeniach wynikających z eksploatacji tunelu.

\section{Zakończenie}

W Polsce wybudowano ostatnio tunele ponad 500 metrowej długości w Warszawie i Katowicach i planuje się dalsze, między innymi trzy tunele drogowe w Trójmieście. Jeden $\mathrm{z}$ tych tuneli pod Martwą Wisłą w ciągu Trasy Sucharskiego (łączącej Port Gdański z układem dróg krajowych) będzie miał długość ok. $0,8 \mathrm{~km}$ i będzie zdejmował ruch tranzytowy z gęsto zamieszkałego Śródmieścia Gdańska (w tym ruch pojazdów z materiałami 
niebezpiecznymi do portu i zakładów przemysłowych położonych w dzielnicy portowej).

Analiza efektywności Trasy Sucharskiego (łącznie z tunelem) wskazuje, ze jej wybudowanie spowoduje w roku (2012) oddania trasy do ruchu [16]:

- skrócenie łącznego czasu podróży o 7,9 mln godz./ rok,

- zmniejszenie zużycia paliwa o $10,8 \mathrm{mln} 1$ / rok,

- zmniejszenie emisji CO o 0,7 mln ton/rok, a NOx o 0,1 mln ton/rok,

- zmniejszenie liczby zdarzeń drogowych o 313 wypadków i kolizji/rok, a ofiar wypadków o 44 osoby/rok,

- zmniejszenie łącznych kosztów ruchu o $166 \mathrm{mln}$ zł/rok..

Natomiast ryzyko wystąienia katastrofy o rozmiarze powyżej 10 osób śmiertelnych na $1 \mathrm{~km}$ na rok (liczone według metody szwajcarskiej) może wynieść:

- w tunelu pod Martwa Wisłą:

○ w przypadku dwóch rozdzielonych jezdni: $\mathrm{P}=1,3610^{-6}$,

○ w przypadku jednej jezdni: $\quad \mathrm{P}=2,6210^{-6}$,

- na trasie alternatywnej w Śródmieściu Gdańska: $P=5,3810^{-6}$.

$\mathrm{Z}$ przedstawionego wyliczenia wynika, że ryzyko wystapienia katastrofy powyżej 10 ofiar śmiertelnych w planowanym tunelu jest małe i znajduje się w obszarze ryzyka akceptowanego według kryteriów przedstawionych na rys. 4. Te obliczenia ryzyka są jednak bardzo uproszczone i nie uwzględniają wszystkich polskich warunków. Dlatego konieczne jest opracowanie metody zarządzania ryzykiem w tunelach drogowych, ujmującej polskie warunki ruchu i zachowania uczestników ruchu drogowego.

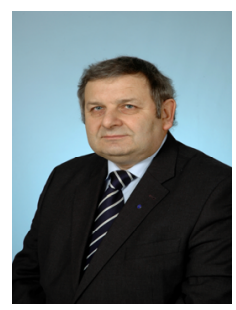

Phd Eng. Kazimierz Jamroz, Gdańsk University of Technology, Highway Engineering Department, speciality: traffic engineering, road safety, intelligent transport systems 